\title{
Effects of silicon on the penetration and reproduction events of Meloidogyne exigua on coffee roots
}

\author{
Rodrigo Vieira Silva (1,2*); Rosângela D’Arc de Lima Oliveira ('); Patrícia da Silva Ferreira ('); \\ Douglas Barbosa Castro ('); Fabrício Ávila Rodrigues (') \\ (1) Universidade Federal de Viçosa (UFV), Departamento de Fitopatologia, Av. PH Rolfs, s/n, 36570-000 Viçosa (MG), Brasil. \\ (2) Instituto Federal Goiano (IF Goiano), Departamento de Agronomia, Caixa Postal 92, 75650-000 Morrinhos (GO), Brasil. \\ $\left({ }^{*}\right)$ Corresponding author: rodrigo.silva@ifgoiano.edu.br
}

Received: Oct. 13, 2014; Accepted: Dec. 28, 2014

\begin{abstract}
Considering that the root-knot nematode Meloidogyne exigua has caused great yield losses to coffee production in Brazil, this study aimed to determine whether the penetration and the reproduction events of this nematode on the roots of plants from two coffee cultivars with different levels of basal resistance to this nematode could be affected by silicon (Si). Coffee plants from the cultivars Catuaí and IAPAR 59, which are susceptible and resistant, respectively, to M. exigua, were grown in pots containing Si-deficient soil that was amended with either calcium silicate (+Si) or calcium carbonate (-Si). The Si concentration on the root tissue significantly increased by 159 and 97\% for the +Si plants from the cultivars Catuaí and IAPAR 59, respectively, compared to the -Si plants of these cultivars. The population of $M$. exigua, the number of galls and the number of eggs were significantly reduced on the roots of the +Si plants of the cultivars Catuaí and IAPAR 59 compared to the -Si plants of these cultivars. It was concluded that the development and reproduction events of $M$. exigua were negatively impacted on the roots of coffee plants supplied with Si.
\end{abstract}

Key words: Coffea arabica, host resistance, plant nutrition, root-knot nematode.

Meloidogyne exigua Goeldi is the most widely distributed nematode species in the areas where coffee (Coffea arabica) is grown in Brazil (Campos \& Villain, 2005). In the Minas Gerais State, the main coffee producer in Brazil, it is estimated that $M$. exigua is present in almost all municipalities where coffee is grown and in more than $50 \%$ of the coffee-producing areas in the other Brazilian states (Castro et al., 2008). On coffee plantations in Rio de Janeiro State, yield losses caused by $M$. exigua reached 45\% (Barbosa et al., 2004).

The use of nematicides has been avoided both in small and large areas due to their high cost and the risk that they bring to the applicator and also to the environment. Cultivars that are resistant to $M$. exigua are still scarce in the market, and the continued use of the available resistant cultivars has contributed to overcoming the host resistance because this genetic inheritance is race-specific. In light of these concerns, silicon $(\mathrm{Si})$ shows promising as an environmentally friendly choice. The Si has the potential to decrease the intensity of important diseases in several crops, especially cereals and some dicots (Datnoff et al., 2007). Silva et al. (2010) investigated the effect of Si on coffee resistance to $M$. exigua at the biochemical level and found that the high Si concentration in the roots of plants supplied with Si contributed to reduce the number of galls and the number of eggs due to an increase in the concentration of lignin-thioglycolic acid derivatives and the activities of peroxidases, polyphenoloxidases and phenylalanine-ammonia lyases.

This study aimed to investigate whether the penetration and the reproduction of $M$. exigua on the roots of coffee cultivars with different resistance phenotypes could be affected by $\mathrm{Si}$.

The Brazilian soil type that was used in the experiments was a Si-deficient typical Acrustox red yellow latosol that was collected at the Triângulo Mineiro savannah area with $530 \mathrm{~g}$ of clay $\mathrm{kg}^{-1} ; \mathrm{pH}$ in $\mathrm{KCl}=4.8 ; \mathrm{P}$ (Mehlich-1) $=0.5 \mathrm{mg} \mathrm{dm}^{-3} ; \mathrm{K}$ (Mehlich-1) $=13 \mathrm{mg} \mathrm{dm}^{-3} ; \mathrm{Al}^{3+}, \mathrm{Ca}^{2+}$, $\mathrm{Mg}^{2+}$ and $\mathrm{H}+\mathrm{Al}^{3+}=0.1,0.0,0.0$ and $3.8 \mathrm{cmol} \mathrm{dm}_{c}^{-3}$, respectively; base saturation $=2 \%$; and organic matter $=2.3 \mathrm{dag} \mathrm{kg}^{-1}$. The concentration of available $\mathrm{Si}$ (extraction in $\mathrm{CaCl}_{2}$ ) was $11.8 \mathrm{mg} \mathrm{dm}^{-3}$. Each plastic pot was filled with $1 \mathrm{~kg}$ of air-dried, sieved $(5 \mathrm{~mm})$ soil. Wollastonite, which was used as the Si source (calcium silicate; Vansil, 
EW-20, Ipiranga Chemical Co., São Paulo, Brazil), was composed of $24.2 \%$ Si and $31 \% \mathrm{Ca}$ and it was incorporated into each pot at the rates of 0 and $1.25 \mathrm{~g} \mathrm{~kg}^{-1}$ soil, which corresponded, respectively, to 0 and $0.30 \mathrm{~g}$ of elemental Si per pot. Calcium carbonate ( $40 \% \mathrm{Ca}$, Sigma-Aldrich, São Paulo, Brasil) was added at the rate of $0.97 \mathrm{~g} \mathrm{~kg}^{-1}$ of soil to equilibrate the amount of $\mathrm{Ca}$ in this treatment with the amount that was present in the pots that received $1.25 \mathrm{~g}$ of wollastonite. The amount of Ca among the treatments was fixed at $0.39 \mathrm{~g}$ per pot. The soil in each pot was incubated for 60 days with approximately $65 \%$ of humidity.

Coffee seeds from the cultivars IAPAR 59 and Catuaí Vermelho IAC 44 (hereafter denominated Catuaí), which are resistant and susceptible to $M$. exigua, respectively, were surface sterilised in $10 \%\left(\mathrm{v} \mathrm{v}^{-1}\right) \mathrm{NaOCl}$ for $1.5 \mathrm{~min}$, rinsed in sterilised water for $3 \mathrm{~min}$ and sowed at the rate of 50 seeds of each cultivar per plastic tray containing washed and sterilised sand. Seedlings in the cotyledonary leaf stage were transplanted at one seedling per pot. The soil in each pot was fertilised before seedling transplanting with $3 \mathrm{~g}$ of simple superphosphate, $0.5 \mathrm{~g}$ of potassium chloride and $0.22 \mathrm{~g}$ of ammonium sulphate per $\mathrm{kg}$ of soil. The plants also received $30 \mathrm{~mL}$ of Hoagland nutrient solution (Hoagland \& Arnon, 1950) every 15 days. Plants were watered as needed. The plants were inoculated with $M$. exigua as previously described by Silva et al. (2010).

The eggs of $M$. exigua were extracted according to the technique that was proposed by Boneti \& Ferraz (1981) and incubated with deionised water in a growth chamber at $26^{\circ} \mathrm{C}$ based on Baermann's method using a bowl instead of a funnel. Nematodes were discarded after daily collection for four days and were maintained in the refrigerator at $8{ }^{\circ} \mathrm{C}$. Each plant was inoculated with $2000 \mathrm{~J} 2(4 \mathrm{~mL})$ distributed in three openings that were positioned $1 \mathrm{~cm}$ from the collar at an approximately 3 -cm depth. Forty-eight hours after inoculation, the plants were removed from the plastic pots and their roots were washed to eliminate any $\mathrm{J} 2$ that had not yet penetrated in order to standardise the age of the $\mathrm{J} 2$ at two days inside the roots. The penetration and development of $M$. exigua were evaluated at 5,10 and 15 days after inoculation (dai) in six plants from each cultivar. The nematodes inside the roots were localised by in situ staining (Bybd et al., 1983) with some adaptations. Root galling of plants from cvs. Catuaí and IAPAR 59 were counted at 120 dai and the reproduction of $M$. exigua was evaluated by the number of eggs (NE) and the number of galls (NG) per root system according to Boneti \& Ferraz (1981). Another group of pots were used for determine the concentration of $\mathrm{Si}$ on the root tissue for each treatment.

The plants were removed from the pots at 120 dai. The roots were shaken to remove the bulk of the soil and washed in sterile deionised water. Roots and shoots were dried for $72 \mathrm{~h}$ at $65^{\circ} \mathrm{C}$ to obtain the dry mass. Roots were ground with a Thomas-Wiley mill to pass through a 40 -mesh screen and used to determine the concentration of $\mathrm{Si}$ according to the colorimetric analysis proposed by Korndörfer et al. (2004). The root tissue was digested with a nitric-perchloric solution $(3: 1, \mathrm{v} / \mathrm{v})$ and the $\mathrm{Ca}$ concentration was determined by atomic absorption spectrophotometry. A $2 \times 2$ factorial experiment, consisting of two Si rates and two coffee cultivars, was arranged in a completely randomised design with six replications. The experiment was repeated once. Each experimental unit consisted of one pot containing one plant. The data from the two experiments were pooled for analysis as indicated by Cochran's test for the homogeneity of variance (Gomez \& Gomez, 1984). The data were subjected to an analysis of variance (ANOVA) and the means were compared by a t-test $(\mathrm{p} \leq 0.05)$ using SAS (SAS Institute, Inc., Cary, NC).

The factors Si rates, coffee cultivars and the interaction Si rates $\times$ coffee cultivars were significant only for the concentration of Si on the root tissue (Table 1). The Si concentration on root tissue significantly increased by 159 and $97 \%$ for the +Si plants from the cultivars Catuaí and IAPAR 59, respectively, compared to that of the -Si plants of these two cultivars. The Si concentration on the root tissue of the $-\mathrm{Si}$ and $+\mathrm{Si}$ plants from the cultivar Catuaí was significantly superior by 26 and $65 \%$, respectively, compared to that of $-\mathrm{Si}$ and $+\mathrm{Si}$ plants from the cultivar IAPAR 59 (Table 1).

Based on the root and the shoot dry weight, the factors $\mathrm{Si}$ rates and coffee cultivars and the interaction $\mathrm{Si}$ rates $x$ coffee cultivars were significantly. The root dry weight was significantly reduced by 12 and $18 \%$ on the roots of the $-\mathrm{Si}$ and $+\mathrm{Si}$ plants, respectively, from the cultivar IAPAR 59 compared to the roots of the $-\mathrm{Si}$ and $+\mathrm{Si}$ plants from the cultivar Catuaí. Significant decreases of 15 and $20 \%$, respectively, for the root dry weight occurred in the roots of the -Si plants from the cultivars Catuaí and IAPAR 59 compared to that of the roots of the $+\mathrm{Si}$ plants from these two cultivars. Significant reductions of 11 and $17 \%$, respectively, on the roots of $-\mathrm{Si}$ and $+\mathrm{Si}$ plants from the cultivar IAPAR 59 compared to that of the roots of the $-\mathrm{Si}$ and $+\mathrm{Si}$ plants from the cultivar Catuaí occurred for the shoot dry weight. The shoot dry weight significantly

Table 1. Silicon $(\mathrm{Si})$ concentration in root tissue of coffee plants from cultivars Catuaí Vermelho IAC 44 (susceptible) and IAPAR 59 (resistant) supplied $(+\mathrm{Si})$ or not $(-\mathrm{Si})$ with silicon at 120 days after inoculation with Meloidogyne exigua

\begin{tabular}{|c|c|c|}
\hline \multirow{2}{*}{ Cultivars } & \multicolumn{2}{|c|}{ Silicon (dag/kg) } \\
\hline & $-\mathbf{S i}$ & $+\mathrm{Si}$ \\
\hline Catuaí & 0.44 bA & $1.14 \mathrm{aA}$ \\
\hline IAPAR & $0.35 \mathrm{bB}$ & $0.69 \mathrm{aB}$ \\
\hline CV (\%) & \multicolumn{2}{|c|}{12.18} \\
\hline
\end{tabular}

Means within a column followed by the same uppercase letter and means within a row followed by the same lowercase letter are not significantly different $(P=0.05)$ according to thet-test. $\mathrm{CV}=$ coefficient of variation. 
decreased by 20 and $14 \%$, respectively, in the - Si plants from the cultivars Catuaí and IAPAR 59 compared to that of the roots of the + Si plants from these two cultivars (Table 2).

The factors Si rates and coffee cultivars and the interaction Si rates $\times$ coffee cultivars were significant for the population of $M$. exigua on the roots of the plants from the cultivars Catuaí and IAPAR 59 (Table 3). The number of $M$. exigua juveniles inside the roots was significantly reduced by 30 and $25 \%$ at 5 dai, by 82 and $77 \%$ at 10 dai and by 78 and $77 \%$ at 15 dai for the $-\mathrm{Si}$ and $+\mathrm{Si}$ plants of the $\mathrm{cv}$. IAPAR 59 compared to that of the $-\mathrm{Si}$ and + Si plants of the cv. Catuaí. For the cv. Catuaí, the population of $M$. exigua was significantly reduced by 26,37 and $25 \%$ at 5,10 and 15 ai, respectively, for the + Si plants compared to that of the -Si plants. For the cultivar IAPAR 59, the population of M. exigua was significantly reduced by $21 \%$ only at 5 dai for the + Si plants compared to that of the -Si plants (Table 3).

The factors Si rates and coffee cultivars and the interaction Si rates $\times$ coffee cultivars were significant for the root and shoot dry weights (Table 4). The NG were significantly reduced by 97 and $20 \%$, respectively, on the roots of the $+\mathrm{Si}$ and - Si plants from the cv. IAPAR 59 compared to those of the roots of the $+\mathrm{Si}$ and $-\mathrm{Si}$ plants from the cv. Catuaí. Significant decreases of 99 and $25 \%$, respectively, for the NE occurred in the roots of the $+\mathrm{Si}$ and $-\mathrm{Si}$ plants from the $\mathrm{cv}$. IAPAR 59 compared to the roots of the $+\mathrm{Si}$ and $-\mathrm{Si}$ plants from the cv. Catuaí. For the cv. Catuaí, the NG and NE were significantly reduced by 26 and $30 \%$, respectively, for the + Si plants compared to those of the -Si plants (Table 4).

The results of the present study not only support the concept that $\mathrm{Si}$ can increase the resistance of several plant species to many root pathogens (Fauteux et al., 2005; Silva et al., 2010), but also provides novel evidence that the penetration and the reproduction of $M$. exigua on the roots of the coffee plants, especially in the most susceptible cultivar, were negatively affected by Si. There was a drastic decrease in penetration of juveniles, and even when there was penetration, the female development was delayed with consequent reduction in both NG and NE indicating to occur resistance to pre and post-penetration of the nematode. The concentration of $\mathrm{Si}$ on the roots of plants supplied with $\mathrm{Si}$ from both cultivars ranged from 0.4 to $1.2 \mathrm{dag} / \mathrm{kg}$, which

Table 2. Dry weight of roots (DWR) and shoot (DWS) of coffee plants from cultivars Catuaí Vermelho IAC 44 (susceptible) and IAPAR 59 (resistant) supplied $(+\mathrm{Si})$ or not $(\mathrm{Si})$ with silicon at 120 days after inoculation with Meloidogyne exigua

\begin{tabular}{|c|c|c|c|c|}
\hline \multirow{2}{*}{ Cultivars } & \multicolumn{2}{|c|}{ DWR (g) } & \multicolumn{2}{|c|}{ DWS (g) } \\
\hline & $-\mathrm{Si}$ & $+\mathrm{Si}$ & $-\mathbf{S i}$ & $+\mathrm{Si}$ \\
\hline Catuaí & $1.24 \mathrm{bA}$ & $1.52 \mathrm{aA}$ & $3.24 \mathrm{bA}$ & $3.91 \mathrm{aA}$ \\
\hline IAPAR & $1.06 \mathrm{bB}$ & $1.21 \mathrm{aB}$ & $2.79 \mathrm{bB}$ & $3.13 \mathrm{aB}$ \\
\hline CV (\%) & & & & \\
\hline
\end{tabular}

Means followed by the same lowercase number in a line and uppercase letter in a column do not differ among themselves by Tukey's test at $5 \%$ probability row. CV $=$ coefficient of variation.

Table 3. Number of J2, J3 and J4 of Meloidogyne exigua on the roots of coffee plants from cultivars Catuaí Vermelho IAC 44 (susceptible) and IAPAR 59 (resistant) at 5,10 and 15 days after inoculation with the nematode

\begin{tabular}{|c|c|c|c|c|c|c|c|}
\hline \multirow{2}{*}{ Cultivars } & \multirow{2}{*}{ Stages } & \multicolumn{2}{|c|}{5 dai } & \multicolumn{2}{|c|}{10 dai } & \multicolumn{2}{|c|}{15 dai } \\
\hline & & $-\mathrm{Si}$ & $+\mathrm{Si}$ & $-\mathrm{Si}$ & $+\mathrm{Si}$ & $-S i$ & $+\mathrm{Si}$ \\
\hline \multirow{3}{*}{ Catuaí } & 12 & 146 & 108 & 139 & 86 & 21 & 24 \\
\hline & $\mathrm{J} 3$ and $\mathrm{J} 4$ & 0 & 0 & 17 & 12 & 113 & 77 \\
\hline & Total & $146 \mathrm{aA}$ & $108 \mathrm{bA}$ & $156 \mathrm{aA}$ & 99 bA & $134 \mathrm{aA}$ & $101 \mathrm{bA}$ \\
\hline \multirow{3}{*}{ IAPAR } & 12 & 102 & 81 & 28 & 23 & 13 & 10 \\
\hline & $\mathrm{J} 3$ andJ4 & 0 & 0 & 0 & 0 & 16 & 12 \\
\hline & Total & $102 \mathrm{aB}$ & $81 \mathrm{bB}$ & $28 \mathrm{aB}$ & $23 \mathrm{aB}$ & $29 a B$ & $22 \mathrm{aB}$ \\
\hline
\end{tabular}

Means within a column followed by the same uppercase letter or means within a row that were followed by the same lowercase letter are not significantly different $(P=0$ 05) according to the $t$-test for each evaluation time. J2, J3 and J4 $=$ juveniles at the $2^{\text {nd }}, 3^{\text {rd }}$ and $4^{\text {th }}$ stages, respectively. dai $=$ days after inoculation.

Table 4. Number of galls (NG) and number of eggs (NE) of Meloidogyne exigua per root system of coffee plants from cultivars Catuaí Vermelho IAC 44 (susceptible) and IAPAR 59 (resistant) that were supplied $(+\mathrm{Si})$ or not (-Si) with silicon at 120 days after inoculation with the nematode

\begin{tabular}{|c|c|c|c|c|}
\hline \multirow{2}{*}{ Cultivars } & \multicolumn{2}{|c|}{ NG } & \multicolumn{2}{|c|}{ NE } \\
\hline & $-\mathrm{Si}$ & $+\mathrm{Si}$ & $-\mathbf{S i}$ & $+\mathrm{Si}$ \\
\hline Catuaí & $182 \mathrm{aA}$ & $135 \mathrm{bA}$ & $17,872 \mathrm{aA}$ & 12,564 bA \\
\hline IAPAR & $5 \mathrm{aB}$ & $4 \mathrm{aB}$ & $88 \mathrm{aB}$ & $66 \mathrm{aB}$ \\
\hline CV (\%) & \multicolumn{2}{|c|}{19.44} & \multicolumn{2}{|c|}{23.76} \\
\hline
\end{tabular}

For NG and NE, the means within a column followed by the same uppercase letter or means within a row followed by the same lowercase letter are not significantly different $(P$ $=0.05$ ) according to the $\mathrm{t}$-test. $\mathrm{CV}=$ coefficient of variation. 
is less than what has been reported for rice, known as an $\mathrm{Si}$-accumulator plant with $\mathrm{Si}$ concentration on shoots up to 8\% (Dallagnol et al., 2009; Datnoff et al., 2007). However, the $\mathrm{Si}$ concentration on the roots of coffee plants played a pivotal role, based on the innate physiological capacity of coffee plants to take up this element from the soil solution, in negatively impacting the penetration of the juveniles of $M$. exigua and the further development of galls and the nematode's eggs in addition to improving the plant growth. Carré-Missio et al. (2009) observed an increase of 100\% in the $\mathrm{Si}$ concentration in the roots of coffee plants that were grown in hydroponic culture containing $\mathrm{Si}$ compared to plants that were grown in the absence of this element. The authors found that the coffee plants were not efficient in translocating $\mathrm{Si}$ from the roots to the shoots and, therefore, the coffee leaf rust severity did not decrease. The mechanisms behind the variation in the absorption and accumulation of $\mathrm{Si}$ in the shoots of many plant species, including C. arabica, need to be determined.

The reduction in penetration and reproduction of $M$. exigua on the roots of plants from the susceptible cv. Catuaí indirectly indicates an increase in the basal level of resistance potentiated by Si. By contrast, Si did not have any effect on the penetration and reproduction of $M$. exigua on the roots of plants from cv. IAPAR 59 because of the high level of resistance of this cultivar. Anthony et al. (2005) noted that plants from cultivar IAPAR 59 presents HR-type reaction, involving the $M e x-1$ gene, by cellular alterations, occurring the condensation of cytoplasm in feeding sites of $\mathrm{J} 2$, an increase in the size of the nucleus and retraction of the plasmatic membrane of the cell wall.

Based on the results of the present study, it can be concluded that the penetration and reproduction events of $M$. exigua were negatively impacted on the roots of coffee plants supplied with Si.

\section{REFERENCES}

Anthony, F., Topart, P., Martinez, A., Silva, M., \& Nicole, M. (2005). Hypersensitive-like reaction conferred by the Mex-1 resistance gene against Meloidogyne exigua in coffee. Plant Pathology, 54, 476-482. http://dx.doi.org/10.1111/j.1365-3059.2005.01239.x.

Barbosa, D. H. S. G., Vieira, H. D., Souza, R. M., Viana, A. P., \& Silva, C. P. (2004). Field estimates of coffee yield losses and damage threshold by Meloidogyne exigua. Nematologia Brasileira, 28, 49-54.
Boneti, J. I. S., \& Ferraz, S. (1981). Modificação do método de Hussey \& Barker para extraçáo de ovos de Meloidogyne exigua de raízes de cafeeiro. Fitopatologia Brasileira, 6, 553.

Bybd, D. W., Kirkpatrick, T., \& Barker, K. R. (1983). An improved technique for clearing and staining plant tissues for detection of nematodes. Journal of Nematology, 15, 142-143. PMid:19295781.

Campos, V. P., \& Villain, L. (2005). Nematode parasites of coffee and cocoa. In M. Luc, R. A. Sikora, \& J. Bridge (Eds.), Plant parasitic nematodes in subtropical and tropical agriculture (p. 529-579). Wallingford: CAB Internacional. http://dx.doi.org/10.1079/9780 851997278.0529 .

Carré-Missio, V., Rodrigues, F. A., Schurt, D. A., Pereira, S. C., Oliveira, M. G., \& Zambolim, L. (2009). Ineficiência do silício no controle da ferrugem do cafeeiro em solução nutritiva. Tropical Plant Pathology, 34, 416-421.

Castro, J. M. C., Campos, V. P., Pozza, E. A., Naves, R. L., Andrade, W. C., Jr., Dutra, M. R., Coimbra, J. L., Maximiniano, C., \& Silva, J. R. C. (2008). Levantamento de fitonematoides em cafezais do Sul de Minas Gerais. Nematologia Brasileira, 32, 56-64.

Dallagnol, L. J., Rodrigues, F. A., Mielli, M. V. B., Ma, J. F., \& Datnoff, L. E. (2009). Defective active silicon uptake affects some components of rice resistance to brown spot. Phytopathology, 99, 116-121.

Datnoff, L. E., Rodrigues, F. A., \& Seebold, K. W. (2007). Silicon and plant disease. In L. E. Datnoff, W. H. Elmer, \& D. M. Huber (Eds.), Mineral nutrition and plant disease (p. 233-246). St. Paul: APS Press.

Fauteux, F., Rémus-Borel, W., Menzies, J. G., \& Bélanger, R. R. (2005). Silicon and plant disease resistance against pathogenic fungi. FEMS Microbiology Letters, 249, 1-6. http://dx.doi.org/10.1016/j. femsle.2005.06.034. PMid:16006059

Gomez, K. A., \& Gomez, A. A. (1984). Statistical procedures for agricultural research (2nd ed.). New York: Wiley.

Hoagland, D. R., \&Arnon, D. I. (1950). The water-culture method for growing plants without soil (Circular, 347). Berkley: University of California Agricultural Experiment Station.

Korndörfer, G. H., Pereira, H. S., \& Nolla, A. (2004). Análise de silício: solo, planta e fertilizante (Boletim Técnico, 2). Uberlândia: Universidade Federal de Uberlândia.

Silva, R. V., Oliveira, R. D. L., Nascimento, K. J. T., \& Rodrigues, F. A. (2010). Biochemical responses of coffee resistance against Meloidogyne exigua mediated by silicon. Plant Pathology, 59, 586-593. http:// dx.doi.org/10.1111/j.1365-3059.2009.02228.x. 